\title{
Quem pode narrar a favela? intelectuais e sujeitos silenciados: autoridade e autorização
}

\author{
Paulo Roberto Tonani do Patrocínio*
}

\begin{abstract}
Resumo
O presente artigo tem como objetivo principal discutir o papel e o lugar do intelectual no cenário cultural contemporâneo a partir de uma revisão bibliográfica que visita alguns dos principais teóricos que se propuseram a refletir sobre a questão, como Michel Foucault, Gilles Deleuze e Gayatri Chakravorty Spivak. Parte-se do pressuposto de que, se outrora o intelectual atuava enquanto porta-voz de sujeitos silenciados, falando em nome destes sujeitos e, dessa maneira, silenciando-os, nos parece que na contemporaneidade não há mais espaço para este tipo de atuação. Além desta revisão bibliográfica, o artigo também analisa o romance Sorria, você está na Rocinha, de Julio Ludemir, obra que tematiza a relação entre intelectual e sujeitos silenciados na cena literária contemporânea em duas perspectivas: no processo de produção da obra e na representação ficcional.
\end{abstract}

Palavras-Chave: Intelectuais. Representação. Marginais. Rocinha.

\section{Who Can Narrate The Slum? Intellectual and Silenced Subjects: Authority and Authorization}

\begin{abstract}
The main aim of this article is to discuss the role and the place of the intellectual in the contemporary cultural scenario, stemming from a bibliographical review which encompasses some of the main theorists who have reflected upon the topic, such as Michel Foucault, Gilles Deleuze and Gayatri Chakravorty Spivak. It is assumed that if earlier the intellectual acted as an advocate of the silenced ones, speaking in the name of these subjects and, in this way, silencing them, in the contemporaneity there is no place for this kind of procedure. In addition to a bibliographical review, this article also analyses the novel Sorria, você está na Rocinha (Smile, you are in Rocinha), by Julio Ludemir, which addresses the relationship between intellectual and silenced subjects in the contemporary literary scenario in two perspectives: in the process of the production of work and in the fictional representation.
\end{abstract}

Keywords: Intellectuals. Representation. Marginal subjects . Rocinha.

* Professor Adjunto da Faculdade de Letras da Universidade Federal do Rio de Janeiro. 
Mas, o que há, enfim, de tão perigoso no fato de as pessoas falarem e de seus discursos proliferarem indefinidamente?

Onde, afinal, está o perigo?

(Michel Foucault, A ordem do discurso)

Michel de Certeau, em A invenção do cotidiano 2, define a cidade enquanto um "teatro de uma guerra de relatos". Ainda que breve, a definição apresentada pelo autor serve como referência para o estabelecimento de um horizonte de questões acerca da produção literária brasileira contemporânea que se ocupa da representação da experiência urbana. A partir da leitura produzida por Certeau, é possível identificarmos o princípio prismático da subjetividade que determina a forma de narrar e ler a cidade. Ao ser classificada enquanto um palco de uma disputa discursiva, a cidade surge como espaço que se constrói não apenas em sua materialidade física, mas, igualmente, no próprio ato narrativo.

A edificação da narrativa resulta no estabelecimento de uma imagem para a cidade que entra em choque com outras imagens já existentes, evidenciando a perpetuação de uma guerra de relatos. No entanto, conforme o autor afirma, tal conflito é operado no espaço da performance e tem como cenário o campo da fabulação: o teatro. Por esse viés, não se trata do estabelecimento dos relatos enquanto verdades acerca da cidade, mas, sobretudo, como construções discursivas que refletem a subjetividade do sujeito que as produziu. No entanto, a assertiva de Certeau recebe um novo contorno quando lida em diálogo com as clivagens produzidas pela emergência de novos sujeitos da enunciação. A ideia de um confronto bélico, expresso pelo termo guerra de relatos, surge igualmente como metáfora possível para nomear a disputa simbólica existente entre as produções discursivas de autores marginais - estou aqui me referindo em especial aos escritores reunidos sob a égide da Literatura Marginal, em confronto com obras assinadas por intelectuais não pertencentes às periferias urbanas. Pensar o diálogo entre literatura e cidade na literatura brasileira contemporânea significa estar diante da alteridade entre intelectuais e marginais e, principalmente, adentrar as representações e autorrepresentações de territórios marginais, visitando as favelas, periferias e subúrbios que servem de palco para textos literários, sejam estes narrativas ficcionais ou versos poéticos.

Pensar a cidade enquanto o palco de uma guerra de relatos nos conduz a questionar: quem detém o direito sobre a representação da imagem do Outro marginalizado? Afinal, diante da emergência de novos sujeitos da enunciação empenhados em produzir sua própria autorrepresentação literária, somos inclinados a interrogar se o intelectual ainda pode ser porta-voz de grupos minoritários? Utilizo a denominação "intelectuais" não apenas para aludir aos profissionais letrados acadêmicos, mas, principalmente, recorro ao termo para fazer referência a escritores, cineastas, fotógrafos, artistas plásticos, entre outros. Dessa forma, o debate sobre o papel do intelectual me serve como matriz teórica para aprofundar a discussão sobre a relação entre produtores de obras ficcionais e a população marginalizada representada em tais discursos. Tais questionamentos surgem aqui derivados da definição de Michel de Certeau e assumem a feição de uma espécie de bússola que me conduzirá na investigação acerca do lugar do intelectual na cena contemporânea. Para alcance deste objetivo, será realizada uma revisão bibliográfica sobre o tema e analisarei o romance Sorria, você está na Rocinha, de Julio Ludemir, obra que tematiza de maneira nodal a relação entre intelectual e marginais na cena literária contemporânea.

O exame sobre o lugar e o papel do intelectual na contemporaneidade impulsiona não somente uma reflexão teórica, mobiliza também a produção de um novo modelo de mediação e de intervenção na esfera pública e, sobretudo, uma nova forma de diálogo com sujeitos silenciados.

O documentário À margem da imagem (2002), de Evaldo Mocarzel, pode ser tomado como um exemplo deste exercício de reflexão sobre o papel de mediador exercido pelo intelectual ao colocar em xeque os limites éticos da representação de sujeitos marginais. O intuito do diretor não é tão somente dar visibilidade aos que estão marginalizados, Mocarzel realiza um ato de maior vulto ao questionar 
os próprios limites - narrativos e imagéticos - da representação desses sujeitos. Dessa forma, os moradores de rua de São Paulo são registrados não apenas sendo arrebanhados mediante pagamento para depor; é documentada também a crítica desses entrevistados depois de uma primeira projeção do filme que busca representar as suas próprias histórias e imagens, ainda como curta-metragem.

Neste jogo intertextual, os sujeitos / personagens do documentário passam a figuração de agentes do processo simbólico, podendo inferir sobre as diferentes aproximações e discordâncias da representação feita pelo diretor. Em À margem da imagem encontramos a insistência na impossibilidade de traduzir o discurso do marginal para o discurso da cultura dominante, como se este último fosse, inquestionavelmente, o lugar por excelência onde se configuram as forças políticas discursivas que atiraram estes sujeitos/personagens à margem da sociedade. Evaldo Mocarzel opta por registrar a tensão que se instaura entre os espaços discursivos do olhar do cineasta e o dos marginalizados. Desta forma, tão importante quanto compreender o papel das representações da margem da cidade é perceber que estas representações são sempre elaboradas a partir do lugar da enunciação do discurso. Dessa forma, a fala de sujeito em situação de rua captada pelo diretor e o olhar do diretor representado pela câmera são construções subjetivas que afirmam o local da enunciação, inviabilizando assim a produção de uma representação que dá voz aos silenciados. O resultado é justamente uma operação oposta à atitude paternalista dos intelectuais que deixam o marginalizado falar por acreditar que a simples locução desses sujeitos elimina qualquer tensão produzida entre as figurações produzidas pela margem e quem as veicula. O documentário $\mathbf{O}$ prisioneiro da grade de ferro, de Paulo Sacramento, pode ser acionado como um exemplo deste último procedimento citado.

Em semelhança ao filme de Evaldo Mocarzel, o longa-metragem de Paulo Sacramento também visa narrar o cotidiano de um grupo marginalizado - neste caso os prisioneiros da Casa de Detenção de São Paulo, o Carandiru. O diferencial de $\mathbf{O}$ prisioneiro da grade de ferro é o ponto de vista da narração, que pretende construir o discurso a partir dos próprios sujeitos / personagens. Para tal intento foram necessárias diferentes oficinas de produção de vídeo para os presidiários. O resultado buscado é a veiculação de um discurso livre de interferência do intelectual mediador, oferecendo, tanto para os presidiários, como para os espectadores do vídeo, um relato "autêntico" e "real" sobre o cotidiano daqueles que vivem numa esfera não apenas invisível da sociedade, mas inviolável: a prisão.

É importante notar que a produção do documentário surge como uma espécie de resposta ao longametragem Carandiru, de Hector Babenco, lançado em 2003. Inspirado no livro Estação Carandiru, de Drauzio Varela, o filme de Babenco apresenta uma perspectiva que pode ser nomeada como distanciada sobre o cotidiano no Casa de Detenção, não ofertando um olhar de dentro do presídio. Em um movimento oposto, $\mathbf{O}$ prisioneiro da grade de ferro representa de modo explícito a busca por uma autorrepresentação, promovendo um discurso que possa expressar a perspectiva dos próprios detentos sobre o presídio. Dessa forma, torna-se perceptível o empenho, o desejo e o esforço de não interferir na produção discursiva do Outro. Paulo Sacramento, ao optar por capacitar os presidiários para produzirem seu próprio discurso, deseja operar apenas como um veículo de enunciação, acreditando que a simples entrega da câmera simboliza a possibilidade de exame do espaço da prisão a partir da lógica do marginal.

Entre estas duas percepções de abordagem do marginalizado - a tensão da impossibilidade de representar o Outro, realizada por Eduardo Mocarzel, e a busca por uma veiculação do discurso do Outro livre de interferência, preconizada por Paulo Sacramento - equilibra-se a análise contemporânea sobre a posição do intelectual frente às camadas marginalizadas e silenciadas. Utilizo os apontamentos realizados por Margery Fee, no artigo "Who can write as Other?", como referência para pensar esta intricada relação:

(...) podem os grupos majoritários falar como se fossem as minorias? Os brancos como se fossem negros ou pardos, os homens como se fossem mulheres, os intelectuais como 
se fossem operários? Caso afirmativo, como podemos diferenciar juízos preconceituosos e reacionários, generalizações aproveitadoras, romantizações pendendo ao estereótipo, tipificações indulgentes e visões imparciais e transformadoras? (FEE, 1995, p. 242) ${ }^{2}$

Margery Fee não oferece uma resposta que encerre a questão; ao contrário, potencializa o debate. Ela percebe que a fala sobre o Outro pressupõe um posicionamento do enunciador do discurso. Compreender o que está subjacente ao discurso e analisar quais as consequências de tal veiculação passa a ser a principal função do crítico. Para Fee não importa, em primeira instância, quem produziu a escrita e narrou o Outro. A crítica australiana visa, antes de tudo, observar como a identidade do sujeito produtor do discurso é revelada no ato de escrita sobre o Outro. Nessa leitura, o ato de colocar-se como porta-voz de grupos minoritários passa a sofrer uma drástica fratura. Ao evidenciar que qualquer fala sobre um grupo distinto significa, antes de tudo, um posicionamento - negativo ou positivo - do intelectual frente à camada que deseja representar. Margery Fee coloca em detrimento do ideal utópico de alguns intelectuais ocidentais o ato de representar o Outro de forma autêntica.

Se o debate aqui proposto surge em decorrência de uma série de produtos literários contemporâneos, o pensamento crítico ocidental há muito produz interrogações acerca desta questão. Exemplo disto é a conversa entre Michel Foucault e Gilles Deleuze, em 1972, intitulada Os intelectuais e o poder. No diálogo, Foucault já anunciava a necessidade de aparecimento de uma nova forma de engajamento do intelectual, não mais como aquele que dizia a verdade aos que ainda não a viam e em nome dos que não podiam dizê-la:

Ora, o que os intelectuais descobriram recentemente é que as massas não necessitam deles para saber; elas sabem perfeitamente, claramente, muito melhor do que eles; e elas o dizem muito bem. Mas existe um sistema de poder que barra, proíbe, invalida esse discurso e esse saber. Poder que não se encontra somente nas instâncias superiores da censura, mas que penetra muito profundamente, muito sutilmente em toda a trama da sociedade. Os próprios intelectuais fazem parte desse sistema de poder, a "ideia" de que eles são agentes da "consciência" e do discurso também faz parte desse sistema. O papel do intelectual não é mais o de se colocar 'um pouco na frente ou um pouco de lado' para dizer a muda verdade de todos; é antes o de lutar contra as formas de poder exatamente onde ele é, ao mesmo tempo, o objeto e o instrumento; na ordem do saber, da "verdade", da "consciência", do discurso. (FOUCAULT, 1979, p. 71.)

Na leitura de Foucault, a existência de um sistema de poder próprio ao exercício intelectual subordina a "fala das massas", inferiorizando-as frente ao discurso científico e acadêmico. Nesta concepção, pouco importa se o intelectual "se coloca um pouco na frente ou um pouco ao lado" das massas, pois, independentemente da posição assumida, seja negando ou não o papel de porta-voz dos desejos dos grupos socialmente marginalizados, o discurso intelectual figura como detentor de um poder de verdade dotado de uma aura unívoca. No entanto, Foucault esclarece que

Não se trata de libertar a verdade de todo sistema de poder - o que seria quimérico na medida em que a própria verdade é poder - mas de desvincular o poder da verdade das formas de hegemonia (sociais, econômicas, culturais) no interior das quais ela funciona no momento. Em suma, a questão política não é o erro, a ilusão, a consciência alienada ou a ideologia, é a própria verdade. (FOUCAULT, 1979, p. 14.)

Tais reflexões entre Deleuze e Foucault emergem a partir de um debate sobre a relação entre prática e teoria, colocando em cena não apenas questionamentos acerca do papel do intelectual, mas,

2 Do original: (...) can majority group members speak as minority members, Whites as people colour, men as women, intellectuals as working people? If so, how do we distinguish biased and oppressive tacts, exploitative popularizations, sterotyping romantizations, sympathetic identifications and resistant, transformative visions? (Fee, 1995, p. 242. Tradução nossa). 
sobretudo, a estruturação de um novo conceito de representação. É nesta clave que Deleuze lembra que o seu interlocutor foi o primeiro a denunciar a "indignidade de falar pelos outros":

A meu ver, você [Foucault] foi o primeiro a nos ensinar - tanto em seus livros quanto no domínio da prática - algo fundamental: a indignidade de falar pelos outros. Quero dizer que se ridicularizava a representação, dizia-se que ela tinha acabado, mas não se tirava a consequência desta conversão 'teórica', isto é, que a teoria exigia que as pessoas a quem ela concerne falassem por elas próprias. (FOUCAULT, 1979, p. 72.)

Silenciar-se frente aos grupos marginalizados - que, no caso específico do diálogo entre Foucault e Deleuze, eram os prisioneiros - foi a medida necessária para possibilitar a emergência destas vozes. A conversão teórica de que nos fala Deleuze comporta não apenas a fala dos sujeitos silenciados, mas igualmente a insurreição de saberes locais, esquecidos e inferiorizados perante a ciência. Contudo, tal perspectiva teórica foi claramente deturpada, favorecendo a compreensão, para uma parcela de intelectuais, de que o papel a ser assumido frente a estes grupos marginalizados deveria ser passivo, beneficiando o retorno à fala viva do sujeito dominado. Na proposta engendrada por Deleuze e Foucault, não localizamos a defesa de uma simples escuta da pureza da diferença a partir destas vozes silenciadas. Está em jogo o movimento de análise dos mecanismos do poder discursivo que, ao filtrarem a fala destes sujeitos, a desqualificam.

Formulação semelhante é realizada por José Carlos Bruni, no artigo "Foucault: o silêncio dos sujeitos" (Bruni, 1989). O diferencial de Bruni é o empenho por localizar no pensamento do filosofo francês os elementos que colocam em xeque a "indignidade de falar pelos outros" (FOUCAULT, 1981, p205), para citar uma expressão do próprio Foucault:

Para Foucault, a década de 70 comportaria não tanto a insurreição dos sujeitos silenciados, mas os saberes locais, esquecidos, desqualificados, discriminados, inferiorizados perante a Ciência (...) Não se trata, pois, de simplesmente retornar a fala viva do sujeito dominado, ou de ouvir deslumbrado a pureza de sua diferença, mas de analisar os mecanismos de poder da Ciência enquanto instituição que, ao filtrar essa fala, desfiguram-na, desqualificamna, inferiorizam-na. Dir-se-ia que o intelectual, para Foucault, deve, antes de mais nada, ser crítico de suas próprias condições de trabalho que, de modo muito concreto, por seus regulamentos, suas hierarquias, sua organização, sua conformação aos espaços e aos tempos, acabam por assimilar estes saberes, na verdade anti-ciências, como parte "normal" do discurso científico, isto é, os reduzem novamente ao silêncio. Que se pense na universalidade da ciência: por falar em nome de todos os sujeitos, dispensa a fala particular. Antecipando-se à experiência, é como se já possuísse seu sentido ou conceito, supondo conhecido de antemão o conteúdo e o significado das falas dos outros. (BRUNI, 1989, p. 206).

Segundo a leitura de José Carlos Bruni, o cerne da questão frente à relação entre intelectuais e sujeitos marginais não é, necessariamente, a defesa por uma fala autônoma do sujeito que fora silenciado. Mas sim a constatação, semelhante à feita por Margery Fee, de que a produção discursiva do intelectual sobre o marginalizado - mesmo revestida por critérios científicos, ou por este mesmo motivo - sempre será cunhada a partir do referencial do intelectual. Nessa perspectiva, será a partir do aprofundamento no debate sobre a Ciência, antes mesmo de uma discussão do papel do intelectual, que será propiciada a aproximação entre intelectual e marginal. O objetivo é criar uma forma de atuação científica que não silencie o sujeito que está alocado no espaço da marginalização.

Perspectiva semelhante é ofertada por Gayatri Chakravorty Spivak no ensaio "Pode o subalterno falar?” A partir de uma perspectiva crítica pós-colonial, Spivak aborda as diversas impossibilidades de fala dos sujeitos localizados em espaços marginalizados e realiza uma análise das apropriações das falas oriundas dos setores subalternizados. Mesmo que a tradução para o português apresente o substantivo subalterno em masculino, o foco primeiro de leitura de Spaivk são as mulheres subalternas 
indianas. A autora examina diversos exemplos recolhidos da história indiana e, contrariando as perspectivas mais otimistas, adverte sobre a impossibilidade de fala destas mulheres: "O subalterno não pode falar. Não há valor algum atribuído à 'mulher' como item respeitoso nas listas de prioridades globais. A representação não definhou. A mulher intelectual como uma intelectual tem uma tarefa circunscrita que ela não deve rejeitar como um floreio" (SPIVAK, 2010, p.126).

A afirmação da impossibilidade de fala do subalterno é acompanhada da identificação de um novo modelo de intervenção a ser trilhado pelos intelectuais. A rejeição de Spivak em dar voz aos subalternos está calcada na constatação de que seja como objeto - retratado na sua condição de vítima - seja na condição de sujeito - quando recebe o benefício da fala por meio da qual tem ocasião de se expressar - a sua imagem e a sua voz, em ambos os casos, já são elementos de uma mediação própria ao código linguístico e ao código cultural dominantes, constituindo "uma forma de violência epistêmica" para citar uma expressão utilizada pela autora. Dessa forma, a fala do subalterno, independentemente de sua forma enunciativa, é apropriada pela cultura dominante.

A questão retórica que funda o argumento de Spivak - "Pode o subalterno falar?" - não pode ser respondida de forma estanque. Creio que buscar uma resposta para a questão não seja o principal objetivo do ensaio e, principalmente, acredito que não tenha sido este o primeiro impulso dos críticos ao se debruçarem sobre ela. Talvez, o ponto mais importante deste ensaio seja a busca por estruturas teóricas e textuais que possam favorecer a emergência de vozes que foram sulcadas por forças políticas dominantes. De certa forma, a recepção deste ensaio na América Latina foi norteada por este desejo, o de construir um arcabouço teórico que pudesse instrumentalizar as leituras de textos produzidos por sujeitos não pertencentes aos centros hegemônicos de poder, favorecendo, assim, um referencial que possibilitasse colocar em relevo a condição cultural e social dos autores dos textos. Claro está que estamos lidando com contextos políticos e sociais diversos.

Ao acionar a leitura de Spivak enquanto referencial teórico que me auxiliará na edificação de um horizonte de questões, não estou propondo uma equiparação entre os sujeitos periféricos brasileiros que assumem o papel de autores e o subalterno analisado pela crítica. A referência ao ensaio de Spivak tem como objetivo propor uma reflexão sobre as possibilidades e impossibilidades de expressão de uma camada social tradicionalmente silenciada. Contudo, a análise produzida por Spivak não é pacífica e, muito menos, condescendente. A autora não busca uma saída facilitada para a questão e, além disso, nos choca - este é certamente o melhor termo para qualificar a reflexão proposta: o choque - ao afirmar que a impossibilidade de falar do subalterno, o fato de estes não terem voz, é a primeira, e quem sabe a única, condição de sua situação política e social. Além disso, a autora instaura uma perspectiva inovadora em sua interpretação, quando afirma que ao intelectual resta falar por si. O papel do intelectual, nesta leitura, é investigar o quanto seus próprios métodos de análise carregam privilégios institucionais e favorecem a manutenção do subalterno como objeto e, por conseguinte, silenciado.

Diante do quadro construído acima, meu olhar crítico se direciona para uma abordagem do romance Sorria, você está na Rocinha, de Júlio Ludemir, com o intuito de analisar a forma como a obra representa a disputa simbólica entre intelectuais e marginais. A escolha da obra deriva da percepção de que o romance surge como uma espécie de produto cultural resultante dessas clivagens e debates entre intelectuais e sujeitos silenciados. Afinal, além de apresentar em seu bojo as questões mencionadas acima, o próprio Ludemir foi interpelado em diferentes situações sobre sua autoridade e autorização para a produção da obra, chegando, inclusive, a ser "expulso" da favela, segundo o relato do autor em diferentes veículos midiáticos.

No romance, é narrada uma relação amorosa, não correspondida e tratada em tom melodramático, entre um produtor de moda da Rocinha, Paulete, e o jornalista Luciano que opta por morar na favela 
para pesquisá-la, personagem que pode ser lido como um duplo de Julio Ludemir. O entendimento dúbio é fruto da convergência de elementos biográficos do autor com aspectos relatados no texto ficcional. No entanto, o conceito de roman à clef - romance à chave - seria o mais adequado para nomeá-lo. Afinal, seguindo os preceitos do gênero, Ludemir trata de pessoas reais, sejam eles moradores da favela romanceada ou não, por meio de personagens fictícios.

Dividido em três partes, o romance aborda a tensão instaurada a partir da presença do pesquisador “estrangeiro" na favela. A partir deste fio condutor, o leitor passa a ter contato com uma multiplicidade de personagens e eventos que giram em torno dos personagens Luciano e Paulete.

A primeira parte do romance, denominada "Um dia com 36 horas e 120 mil habitantes", é narrada pelo produtor de moda. Ao ser informado de que Luciano corre risco de morte por ter publicado um artigo em que relata a conivência entre setores da favela com o narcotráfico, Paulete inicia uma "guerra" para proteger o jornalista do "tribunal do tráfico." A partir de uma estrutura maniqueísta, o leitor passa a ter contato com diferentes percepções sobre o referido artigo e, principalmente, sobre a presença de Luciano na Rocinha.

"Os salvados" é o título da segunda parte do romance e faz referência aos manuscritos de Luciano que estão em poder de Paulete. Nessa parte, o leitor entra em contato com a visão de Luciano sobre a Rocinha no período em que lá residiu. É só no final desta parte que é revelado ao leitor o conteúdo do "artigo-bomba" - como define o personagem Airton -, que, ao ser publicado resultou na expulsão do pesquisador da favela.

Já na terceira e última parte do livro, "O legado de Bin Laden”, é narrada a busca de Paulete por Luciano. Após ler toda a produção de Luciano, Paulete decide entregar os diários e as inúmeras fitas com horas de entrevistas coletadas por Luciano na Rocinha. Mas o encontro não ocorre; desiludido e sentindo-se traído, o personagem deixa todo o material com a namorada de Luciano, uma de suas alunas da oficina de modelos que mantém na Rocinha. E fechando o romance encontramos a marcação do local em que foi redigido o livro e o período narrado: "Rio de Janeiro, 15 de dezembro de 2002 a 29 de dezembro de 2003".

Cabe aqui um relato pessoal. Morei na mesma localidade escolhida pelo autor em sua pesquisa, a favela da Rocinha, favela da zona sul do Rio de Janeiro. "Sou nascido e criado na Rocinha", para citar uma expressão popular. Durante os seis meses em que Julio Ludemir morou na localidade, mantive certo contato com o escritor. A presença do autor sempre causou curiosidade, receio e desconfiança, como não poderia deixar de ser. Grande parte do temor e desconfiança era impulsionada pelo constante interesse do autor em conhecer, a partir de relatos dos próprios moradores, o funcionamento do comercio varejista de drogas ou episódios que tinham como principais agentes sujeitos ligados a tal prática. Além disso, de forma frequente o autor utilizava-se de sua publicação anterior, o livro No coração do comando, como uma espécie de cartão de visitas. Fator este que reforçava a desconfiança quanto ao tema que seria enfocado no livro sobre a Rocinha. Afinal, como o autor já havia publicado um romance que tinha como eixo temático o comércio varejista de drogas, o que o impediria de retornar a este assunto em seu livro sobre a Rocinha?

Mas não foi apenas o possível enfoque do livro que despertou aversão à presença do autor na favela. Muitos moradores reagiram de forma negativa à ideia de que novamente a favela seria pesquisada por um "estrangeiro", sem a oferta de nenhum retorno. E nesse ponto a Rocinha possui uma posição de destaque, por estar na zona sul da cidade, portanto, próxima dos bairros de elites; e, principalmente, por ser tida como a maior favela da América Latina, ela foi objeto de muitos estudos, porém, poucos ofereceram algum retorno para a comunidade.

Vale ressaltar que a ideia de retorno possui muitas nuances e percepções diversificadas sobre a sua forma, podendo ser entendido por alguns moradores como a simples entrega para a comunidade 
do trabalho que utiliza a Rocinha como fonte. Já outros residentes, principalmente os moradores ligados a organizações comunitárias, acreditam que a coleta de informações sobre a Rocinha deva ser guiada por um princípio ético que crie um compromisso social entre pesquisador e objeto. E as pesquisas, além de favorecerem o crescimento profissional e intelectual do pesquisador, devem acrescentar novas perspectivas para os problemas enfrentados pelos moradores da Rocinha. Por fim, uma pequena parcela da população da Rocinha conceitua a ideia de retorno da pesquisa de forma mais pragmática e individualista, afirmando que o morador, ao ser depoente para um pesquisador ou jornalista, deva cobrar uma espécie de honorários. Afinal, justificam, "eles ganham alguma coisa com isso e nós também".

Em síntese, duas questões perpassam a relação conflituosa de Julio Ludemir e a favela da Rocinha: O que será relatado no livro e de que forma a Rocinha irá se beneficiar com ele? Em relação à primeira questão, o autor respondia a ela de forma indireta com a publicação de pequenas crônicas em uma coluna, hoje extinta, no sítio eletrônico www.vivafavela.com.br, no qual eram apresentadas pequenas biografias de moradores da favela e relatos sobre o cotidiano da Rocinha. Produzidas de forma concomitante à pesquisa, suas crônicas, por tratarem de assuntos distintos ao comércio varejista de drogas e ao eleger como personagens moradores que tinham obtido êxito em diferentes esferas sociais, atuavam como legitimadoras de sua presença na Rocinha.

Já o benefício que a publicação poderia oferecer à comunidade nunca foi apresentado de forma clara por parte do autor. Este, para se desvencilhar da acusação de que estava usurpando histórias sem a oferta de um retorno para a comunidade, afirmava que a própria inserção da Rocinha numa publicação como a que desejava produzir já era um benefício, pois, oferecia visibilidade para uma parcela marginalizada socialmente.

No entanto, foi com a publicação de um artigo no, hoje extinto, sítio eletrônico www.rocinhaworld. com que o autor deixou transparecer seu real objeto de estudo e o enfoque que desejava oferecer em seu livro. No artigo, o autor desenvolve a tese de que, ao contrário de outras favelas em que a estrutura do comercio varejista de drogas se faz presente de forma ostensiva, a Rocinha não está submetida ao poder paralelo. Em para justificar sua hipótese, o autor relata uma série de episódios que corroboram sua tese. Além disso, no artigo o autor afirma que este será o objeto de seu livro, e que este terá como estrutura literária a ficcionalização de episódios e histórias reais.

Ao afirmar que o narcotráfico será tema do livro, Julio Ludemir passa a ser uma "visita" incômoda à Rocinha. Soma-se a isso a compreensão de que o ato de relatar eventos que envolvem sujeitos ligados ao comercio varejista de drogas representa uma delação. Dessa forma, Julio Ludemir passa a ser visto como um intruso que objetiva denunciar o funcionamento das engrenagens do comercio varejista de drogas, restando para o autor a fuga da favela e o abandono de seu projeto literário original. Impedido de representar a vida do Outro, resta para o autor ficcionalizar a sua própria vida. O resultado da transposição dos episódios vivenciados pelo autor para a ficção paradoxalmente evidencia um aspecto contrário ao que pretendia defender o autor: a Rocinha tem dono.

O dono da Rocinha, que em princípio poderia designar o chefe do comércio varejista de drogas, aparece cristalizado na figura dos inúmeros personagens que se opõem à presença do pesquisador na favela. Questões como autoridade e legitimação emergem não apenas como conceitos críticos de análise do romance, mas também como elementos romanceados pelo próprio autor, que, em Sorria, você está na Rocinha, edifica uma narrativa que possui como temática a impossibilidade de um estrangeiro relatar a favela.

$\mathrm{O}$ romance ganha status de denúncia quando o autor afirma, em entrevista à revista Época, que fora silenciado por uma engrenagem política comunitária ligada ao comércio de drogas e que fora julgado pelo "tribunal do tráfico" na Rocinha:

Já fui julgado pelo tráfico. Em maio de 2003, entreguei a um site sobre a Rocinha um artigo que mostrava como a economia da favela funcionava independentemente do tráfico. 
Isso incomodou os donos do jornal comunitário oficial da favela. Eu não percebi que, dando força a um site, estava incentivando uma concorrência ao porta-voz oficial daquela comunidade. É ele quem canaliza a maior fonte de recursos para lá, que são os projetos da prefeitura, do governo do Estado, da Federação e do Banco Mundial. As ONGs querem o monopólio da Rocinha, que é uma marca de apelo mundial. Diante desse risco, as lideranças dessas entidades começaram a espalhar que eu teria dito que o morro não tinha dono, como se fosse uma provocação aos comandantes do tráfico. No fim de maio, o líder do tráfico me chamou para conversar. (Rafael Pereira, Os amigos da Rocinha. Revista Época. Rio de Janeiro, 28 de março de 2004).

Chamar para conversar, desenrolar ou falar com os caras, são gírias que designam a eminência de um "julgamento", no qual agentes locais ligados ao comércio varejista de drogas exercem um papel semelhante ao de um juiz. Contudo, sabemos que houve a absolvição de Ludemir, resta conhecermos como esta ocorreu:

Uma liderança da favela, chamada Adriana, foi minha advogada. Eu levei meu artigo para ela ler e consegui que ela me defendesse diante de Lulu e de Willian DJ. Graças a essa participação dela, consegui me livrar. No fim, eu, que faria apenas um livro sobre a história da Rocinha, acabei escrevendo um livro muito mais 'quente'. (Rafael Pereira, Os amigos da Rocinha. Revista Época. Rio de Janeiro, 28 de março de 2004).

Além de apresentar um relato pessoal sobre o seu "julgamento", a passagem acima deixa em evidência um aspecto importante: a nomeação, a partir do nome próprio, dos moradores envolvidos na conflituosa passagem do autor pela Rocinha. Se no romance, Julio Ludemir opta por não designar pelos nomes próprios os moradores que foram contrários à sua presença, recorrendo ao uso de codinomes, em sua entrevista para o semanário, nomeia os moradores que habitam as páginas de seu romance. Procedimento semelhante é adotado pelo autor em entrevista ao jornal Folha de São Paulo, no dia 10 de abril de 2004. Com o título "Livro embaralha ficção e realidade para mostrar vida na Rocinha", a matéria assinada por Sergio Torres, ainda que inserida no caderno cultural do referido jornal, torna-se difícil a classificação do texto, pois sua estrutura transita entre uma resenha que apresenta o romance e um texto jornalístico policial que exerce a função de evidenciar os aspectos testemunhais contidos na obra. O autor da matéria ignora a classificação do livro como "romance" e articula a apresentação do livro de Ludemir a partir da elaboração de um jogo entre ficção e realidade, no qual busca no texto literário evidências da realidade:

Com um pouco de conhecimento sobre a favela, fica fácil descobrir quem é quem durante a leitura das quase 400 páginas. O chefão do tráfico identificado na narrativa pelo apelido Bigode é Luciano da Silva Barbosa, o Lulu, líder da facção criminosa CV (Comando Vermelha) e "dono" (para usar a expressão local) da Rocinha. O dirigente comunitário MC é, na vida real, William de Oliveira, o DJ, eleito neste ano presidente da União PróMelhoramentos da Rocinha, a mais influente associação de moradores da favela. (Sergio Torres. Livro embaralha ficção e realidade para mostrar vida na Rocinha. Folha de São Paulo. São Paulo, 10 de maio de 2004)

É necessário também dizer que, com um pouco de conhecimento sobre a Rocinha, fica fácil descobrir o que é ficcional e o que é o seu reverso. O jogo empreendido por Sergio Torres se revela falho ao simplesmente buscar os duplos da ficção na realidade. Faz-se indispensável a construção de uma leitura do romance que coloque em xeque os fatos narrados. Todavia, o leitor não familiarizado com a história da Rocinha e não conhecedor da estrutura da política comunitária facilmente é levado pela engrenagem ficcional, absorvendo todos os episódios narrados como fatos reais e tornando assim mais complexa a utilização de personagens reais para compor uma história ficcional. 
Ao fundir ficção e realidade num texto que proclama status de denúncia, Julio Ludemir cria uma narrativa semelhante à desejada pelo personagem Luciano, seu possível duplo ficcional no romance, pois deixa em aberto a questão: o que é verdade e o que é ficção? Na segunda parte do livro, momento em que é oferecida ao leitor a possibilidade de leitura dos diários do personagem Luciano, temos contato com a definição do projeto do livro que o personagem almeja escrever:

Conversa com a advogada e amiga Camila, que visitei ontem à noite a propósito do favor que uma prisioneira do Talavera Bruce, sua cliente, me pediu. Falei-lhe do tratamento ficcional que pretendo dar ao livro, para fugir do problema da x-novada. Ela não apenas concordou com a solução, como deu o que pode ser o mote do livro: o que é verdade e o que é ficção nesse universo? (LUDEMIR, op. cit., p. 244).

X-novar é uma expressão que designa na gíria da favela a delação. Quem a faz é o X-9, agente infiltrado pela polícia no morro para investigar e posteriormente apontar - literalmente - com o rosto coberto por uma máscara, os moradores envolvidos com o narcotráfico. O personagem Luciano, como evidencia a passagem acima, não quer exercer tal papel. Mas o tratamento ficcional que o personagem deseja dar ao livro passa a ser uma máscara que desempenha uma função semelhante ao pano que encobre a identidade de um delator. $\mathrm{O}$ diferencial é que a máscara que será utilizada para apontar os envolvidos não pode ser facilmente retirada, ela encoberta, no pior sentido da palavra, a figura do personagem.

Não temos contato com as estratégias utilizadas pelo personagem Luciano para a estruturação do seu livro. Como foi dito anteriormente, o personagem, cumprindo um percurso semelhante ao realizado pelo autor, é impedido de representar a favela. $\mathrm{Na}$ leitura dos diários, temos contato apenas com uma série de apontamentos e suposições que deixam transparecer o olhar atento do pesquisador estrangeiro, mas o registro ficcional a partir deste olhar não foi realizado. Dessa forma, os diários do personagem apresentam a tensão vivida pelo pesquisador no constante questionamento sobre a forma narrativa que deseja utilizar no livro e, principalmente, com que enfoque:

Falar da noite de ontem de modo mais desabrido com certeza há de resolver grandes questões do livro. Vou abri-la com o encontro que tive com o Oscar na Via Ápia, que a propósito tem me trazido problemas, já que estar ali como eu estive ontem, em frente à boca, faz de mim, aos olhos da comunidade, um cara envolvido. Ser um cara envolvido, ou com contexto ou com conceito, pode trazer uma série de vantagens econômicas e até mesmo sexuais, mas para estar fazendo o trabalho que estou fazendo é quase que uma queimação de filme.

Mas tenho a impressão de que ela seria quase que inevitável, já que não é possível escrever um livro sobre a Rocinha sem incluir um importante capítulo sobre a boca da Via Ápia. (LUDEMIR, op. cit., p. 212-3).

A organização dos diários não possui uma estrutura linear, e será a partir de uma leitura fragmentada que o leitor passa a construir a sua percepção sobre o projeto do pesquisador. No entanto, não podemos afirmar que a segunda parte do romance, quando os diários são inseridos na narrativa, corresponda à fala do personagem. Julio Ludemir cria um efeito interessante para oferecer os diários do personagem ao leitor, no qual se tem a percepção de que a inserção da fala do personagem se dá a partir da leitura que Paulete faz dos diários. Nesse sentido, o que fica em evidência é uma dupla impossibilidade de fala sobre a favela. Se no plano temático da obra, Luciano é interpelado pelo narcotráfico que o silencia, na narração dos eventos que corroboraram tal desfecho, em apenas duas passagens temos contato com a fala do personagem, que se reduz a duas conversas por telefone com o personagem Paulete. Na primeira inserção de uma fala do personagem na narrativa, esta se restringe a um cumprimento:

O celular tocou várias vezes seguido, mas eu só percebi que era o meu telefone quando Mike perguntou se não ia atender. Olhei o número no visor. Não o reconheci.

- Paulete!? 
Só pelo fato de Luciano não estar me chamando por um dos inúmeros apelidos que me deu ao longo de nossa convivência - o último foi Molina, o travesti de $\mathrm{O}$ beijo da mulher-aranha, que não vi menos de dez vezes - eu deveria saber que estava com problema. (LUDEMIR, op. cit., p. 25)

Já a segunda inserção de uma fala do personagem Luciano é mais extensa. Em um longo diálogo que ocupa parte significativa do capítulo 7, da primeira parte do romance, temos contato com o desespero de Luciano em salvar sua pesquisa. Em sua fuga da Rocinha, Luciano foi obrigado a jogar todo seu material de pesquisa numa mata na parte alta da favela. E impedido de voltar à localidade, Luciano pede a Paulete que este recolha seus diários e as inúmeras fitas com entrevistas de moradores. A insistência no pedido de um favor a Paulete torna a fala de Luciano redundante e vazia. Além disso, a repetição do pedido de favor coloca em evidência a relação pragmática e utilitária que o personagem pesquisador estabelece com a Rocinha. A reação de Paulete frente à persistência de Luciano é sintomática:

Voltei a ter a sensação de uso. De abuso da bicha favelada de que a cidade só se lembra quando algum pesquisador de merda precisa tirar uma casquinha de nossa pobreza, nossos bandidos bárbaros, nossas domésticas cearenses, nossos birosqueiros inescrupulosos, nossos evangélicos engabelados por astutos pastores. (LUDEMIR, op. cit., p. 128)

O sentimento de uso, de usurpação, tem um certo tom melodramático que deixa transparecer que a reação aborrecida do personagem é fruto de uma paixão não correspondida. Todavia, a afirmação da reincidência deste sentimento coloca em evidência que a tensão estabelecida se dá entre pesquisador e objeto, rompendo a esfera amorosa. A polêmica é reacendida: qual a relação que deve ser estabelecida entre pesquisador e objeto? A resposta é ensaiada pelo próprio personagem Paulete ao elencar as diferentes usurpações que a favela já sofreu, sendo colocada em evidência apenas quando, nas palavras do personagem, "algum pesquisador de merda precisar tirar casquinha de nossa pobreza".

Qual a imagem mais apropriada para definir a forma como o personagem Luciano se relaciona com a comunidade da Rocinha, senão a utilizada por Paulete? O que move Luciano em sua passagem pela favela a não ser a tentativa de apropriar-se das narrativas da comunidade, retirando com desenvoltura dos moradores episódios fragmentados da história da favela? "Tirar uma casquinha", como define o personagem Paulete, passa a ter duas dimensões. Além da extração, há a revelação do que era ocultado pelo fragmento. Dessa forma, além da história da comunidade ser investigada por um estrangeiro, que busca colecionar fatos e personagens marcantes, a futura transposição desta narrativa oralizada para a letra de fôrma será feita a partir do referencial do pesquisador, o que será contado não passará pelo crivo da comunidade.

E será contra esse sentimento de espoliação que muitos personagens do romance se colocarão contrários à ideia de prestarem depoimento para o pesquisador sem a oferta de um pagamento. Dois personagens em especial são representados de forma pejorativa no romance, sobretudo nos trechos relativos aos diários de Luciano, por se negarem a ajudar o pesquisador: Matias e Francisco.

Em relação a Matias, encontramos uma maior benevolência por parte de Luciano, mas é notória a irritação do personagem pelo tratamento indiferente que Matias oferece quando dá entrevista:

Tive a impressão de que ele [Matias] não estava com a menor vontade de dá-la. Tratou-me como se eu fosse um a mais depois de uma longa série de depoimentos que deu, dentre os quais um para a FGV, que para ele vai produzir um livro muito melhor que o meu. Também tem a aura de um índio que não mais aceita espelhos do civilizador, com a consciência de que há em sua terra muitas riquezas que estão sendo espoliadas pelo invasor. (LUDEMIR, 2004, p. 197).

Já em relação ao segundo temos a seguinte definição: "Francisco está sempre atrás de uma grana, como os 100 ou 200 reais que pretende arrancar de mim para me dar uma entrevista” (Idem, p. 239). 
Se o desejo de Francisco em arrancar dinheiro fere o princípio ético do personagem, injuriando todos que cobram por um depoimento, qual o ferimento causado pelo ato de arrancar histórias de uma comunidade? Tal questão se torna mais complexa, dificultando uma resposta estanque, a partir da constatação do próprio Luciano:

Conheci Fabiana, do grupo de teatro de Francisco. Tem a mesma visão prostituída do seu diretor e mentor, de que só se deve dar entrevista se rolar grana. O que eu (ou no máximo a comunidade) vou ganhar com isso? - eis a pergunta inevitável, que venho ouvindo desde que cheguei aqui. Agem como se hoje a visibilidade que a Rocinha tem fosse uma conquista única e exclusiva de seus moradores, não tivesse a menor relação com os esses escritores e sociólogos que vieram tentar descobrir essa estranha América.. (LUDEMIR, 2004, p.210. Grifo meu).

O que está em jogo não é apenas ajudar ou não o pesquisador, conceder ou não entrevistas, mas sim o questionamento sobre a própria visibilidade que será ofertada a partir da publicação do suposto livro. Qual o uso que será feito da fala, da imagem e da história da comunidade? A pergunta que o personagem afirma ser inevitável - O que eu vou ganhar com isso? - é transformada em um indício de individualismo, mas na verdade tal questionamento revela a tomada de consciência por parte desses personagens sobre a importância da visibilidade para uma camada invisível, ou seja, defendem a mesma tese que o personagem Luciano, compreendem que uma narrativa sobre a Rocinha será o fator determinante para formação de um imaginário sobre a mesma. Portanto, além de desejarem preservar a história da comunidade ao não aceitarem abertamente qualquer pesquisador estrangeiro, também não validam a oferta de visibilidade quando esta não corresponde com a imagem que os próprios moradores forjaram para si. É com esse olhar questionador que o personagem Paulete irá criticar a forma como o fotógrafo André Cypriano representou a Rocinha:

Conheci o André [Cypriano].(...) Achei lindas as fotos que tirou da favela (...) discordo da Rocinha negra e miserável que Cypriano registrou em suas lentes. Mas na verdade a minha grande discordância dele se deve ao fato de ter chegado aqui com um discurso altamente sedutor, entrando na vida das pessoas, conquistando um lugar no coração delas. Só lá em casa, por exemplo, tirou fotos de minha irmã, de meu sobrinho e de várias das minhas modelos. Nunca mais voltou sequer para agradecer e principalmente para mostrar o que fez com o tesouro que lhe confiamos. Espero sinceramente que esse não seja o caso de Luciano. (LUDEMIR, 2004, p. 26)

E na segunda parte do romance, temos a apresentação de uma outra interpretação do trabalho do fotógrafo:

Luluca acha que Cypriano tem razão ao retratar uma favela negra. Ela diz que o lugarcomum é o Nordeste, como Regina Casé fez, indo na feira e comendo suas comidas típicas, dançando forró com cearenses no Rocinha's Show, ou seja, mostrando o Nordeste dentro do Rio. Cypriano, segundo Luluca, mostrou uma das faces da favela. (LUDEMIR, 2004, p.310)

O livro ao qual os personagens fazem referência de fato existe, seu título é Rocinha (2005) e quem o assina realmente é o fotógrafo André Cypriano, não há ficcionalização. Em uma edição luxuosa, com textos em português e inglês, Rocinha traz em seu bojo fotografias que colocam em relevo a condição miserável da favela. Os moradores que posam para as fotos são em sua quase totalidade negros, excluindo da representação da favela o grande percentual de nordestinos que lá reside.

Não é meu intuito aferir como de fato ocorreu no plano factual a aproximação entre o fotógrafo e a comunidade da Rocinha. Não busco um possível contraponto à fala do personagem Paulete, que critica o fato de o fotógrafo não ter um compromisso com a comunidade. Julgo que o ponto mais 
relevante nesse aspecto é a observação da necessidade de Julio Ludemir em afirmar que não foi apenas a sua passagem pela favela que gerou conflitos e percepções dúbias. O fotógrafo, ao ser transformado em personagem do romance, serve ao autor como mote para evidenciar a conflituosa relação entre intelectual e favela. A condenação que Paulete faz sobre a atitude de Cypriano em relação à Rocinha pode ser lida como uma crítica prévia, e intertextual, ao romance do qual é personagem. Condena-se, nesse sentido, não a presença do estrangeiro que deseja buscar relatos e imagens, mas sim a forma como este contato ocorre e, principalmente, a relação que se estabelece após a realização do trabalho. Soma-se a isto, a reprovação da revelação da vida íntima dos moradores. "Entrando na vida das pessoas", como declara Paulete na passagem citada anteriormente, para revelar sem pudor as imagens de seu cotidiano.

O próprio livro de André Cypriano deve ser lido enquanto experiência da alteridade entre intelectual e marginalizados. A proposta do fotógrafo é realizar um ato de "aproximação pelo olhar", como proclama o antropólogo Rubem César Fernandes. Coordenador do ONG Viva Rio, o antropólogo personifica o ideal do intelectual mediador, sujeito das luzes que se coloca enquanto elo e porta-voz dos sujeitos silenciados. Não nos causa nenhum tipo de espanto a forma elogiosa com que trata da obra do fotógrafo. Afinal, nas leituras de Rubem César Fernandes, as lentes do fotógrafo não ligam apenas o intelectual à população da Rocinha, mas principalmente aproximam esta camada marginalizada do público leitor. André Cypriano deseja apresentar a favela em uma perspectiva totalizante, opta por não focalizar apenas os moradores, em diferentes registros busca produzir um enquadramento que reflita a densidade demográfica da localidade, ofertando ao público leitor uma visão caótica sobre o emaranhado de casas e a feição labiríntica dos becos. As fotografias revelam, como um verdadeiro clichê, o olhar de um estrangeiro que ambiciona descobrir os segredos e o funcionamento do espaço visitado.

No prefácio do livro Rocinha, o antropólogo Rubem César Fernandes elege o virtuosismo da percepção de Cypriano sobre a favela como elemento de destaque, observando que as lentes do fotógrafo focalizam "a Rocinha no grande panorama, de beleza espetacular (...)". E prossegue o antropólogo:

Os olhos do visitante fotógrafo buscam os olhos dos moradores. Alguns não respondem, incapazes que estão. Muitos, porém, devolvem o convite, deixando-se visitar sem pudor. São crianças brincalhonas, rapazes atléticos, moças que, no olhar, escondem o seu interior. (FERNANDES, 2005,18. Grifo meu).

Não há escolha por parte dos marginalizados, estes devem aceitar a oferta de visibilidade, defende Rubem César Fernandes. A não devoção ao intelectual que adentra a favela passa a ser vista como uma incapacidade. É necessário ser capaz de exibir sua vida privada, despir-se na frente da lente e posar de forma desleixada para evidenciar o flagrante do fotógrafo. É necessário ser objeto de estudo do intelectual, exercer seu papel silencioso de fonte. Negar-se a cumprir tal função, segundo Rubem César Fernandes, revela a total marginalização e incapacidade dos moradores. Em síntese, na leitura do antropólogo, o marginal só é válido, capaz, quando aceita o convite do estrangeiro; é necessário deixar-se ser fotografado, filmado, narrado, representado; não há escapatória, recusar tal convite não é o que se espera por parte desses sujeitos silenciados. Contudo, conforme observado na abertura desse ensaio, a emergência de novos sujeitos da enunciação resulta na reconfiguração do lugar e do papel do intelectual na cena cultura contemporânea. Afinal, conforme adverte Ferréz em frase que defenda a autorrepresentação dos sujeitos marginais e o consequente abandono do lugar de objeto frente ao olhar do intelectual: "Não somos o retrato, pelo contrário, mudamos o foco e tiramos nós mesmos a nossa foto" (FERRÉZ, 2005, p.09). 


\section{Referências}

ATHAYDE, Celso; BILL, M.V. e SOARES, Luiz Eduardo. Cabeça de porco. Rio de Janeiro: Objetiva, 2005.

ATHAYDE, Celso; BILL, M.V. Falcão: meninos do tráfico. Rio de Janeiro: Editora Objetiva, 2006.

BARCELLOS, Caco. Abusado: o dono do morro Dona Marta. 12 edição. Rio de Janeiro: Record, 2004.

BRUNI, José. C. Foucault: o silêncio dos sujeitos. Tempo social. São Paulo: USP, n1: 1989.

CERTEAU, Michel. A invenção do cotidiano 2. Morar, Cozinhar. Petrópolis: Editora Vozes, 2013, $12^{\mathrm{a}}$ edição.

CYPRIANO, André. Rocinha. São Paulo: Editora Senac São Paulo; Rio de Janeiro: Editora Senac Rio; Rio de Janeiro: Senac Nacional, 2005.

FEE, M. Who can write as Other?. In. The post colonial studies reader. (edited by Ashcrof, B;Griffiths, G.; Tiffin. H) London and New York: Routledge, 1995.

FERRÉZ. Capão Pecado. São Paulo: Labortexto Editorial, 2000.

FERRÉZ. (Org.). Literatura marginal: talentos da escrita periférica. Rio de Janeiro: Agir, 2005.

FOUCAULT, Michel. A ordem do discurso. São Paulo: Edições Loyola, 1996.

FOUCAULT, Michel. Microfísica do poder. Rio de Janeiro: Edições Graal, 1979.

LINS, Paulo. Cidade de Deus. São Paulo: Companhia das Letras, 1997.

LUDEMIR, Julio. Sorria, você está na Rocinha. Rio de Janeiro: Editora Record, 2004.

PENNA, J. C. Marcinho VP. Um estudo sobre a construção do personagem. In: Estéticas da crueldade. Ângela Maria Dias e Paula Glenadel. (Org.). Rio de janeiro: Atlântica Editora, 2004.

SPIVAK, Gayatri Chakravorty. Pode o subalterno falar? Belo Horizonte: Editora UFMG, 2010. 